\title{
Retraction: Corrigendum: CDX2/mir- 145-5p/SENP1 Pathways Affect LNCaP Cells Invasion and Migration
}

\section{OPEN ACCESS}

Edited and reviewed by:

Giuseppe Giaccone,

Cornell University, United States

${ }^{*}$ Correspondence:

Frontiers Editorial Office

editorial.office@frontiersin.org

Specialty section:

This article was submitted to Molecular and Cellular Oncology,

a section of the journal

Frontiers in Oncology

Received: 21 July 2021

Accepted: 29 July 2021

Published: 18 August 2021

Citation:

Frontiers Editorial Office (2021) Retraction: Corrigendum: CDX2/mir-

145-5p/SENP1 Pathways Affect LNCaP Cells Invasion and Migration.

Front. Oncol. 11:744980.

doi: 10.3389/fonc.2021.744980
Frontiers Editorial Office*

\section{A Retraction of the Correction Article}

Corrigendum: CDX2/mir-145-5p/SENP1 Pathways Affect LNCaP Cells Invasion and Migration By He J-H, Han Z-P, Zou M-X, He M-L, Li Y-G and Zheng L (2021). Front. Oncol. 11:685219. doi: $10.3389 /$ fonc.2021.685219

The Journal retracts the 18 May 2021 article cited above for the following reasons:

Following publication of the original article, concerns were raised regarding the integrity of the images in the published figures. During the investigation, the authors submitted a correction article which was published during our investigation and which, upon further scrutiny, did not resolve the fundamental issues of image integrity. In the end, the authors have failed to provide a satisfactory explanation during the investigation, which was conducted in accordance with Frontiers' policies.

This retraction was approved by the Chief Editors of Frontiers in Oncology and Chief Executive Editor. The authors did not agree to this retraction.

Copyright $(2021$ Frontiers Editorial Office. This is an open-access article distributed under the terms of the Creative Commons Attribution License (CC BY). The use, distribution or reproduction in other forums is permitted, provided the original author(s) and the copyright owner(s) are credited and that the original publication in this journal is cited, in accordance with accepted academic practice. No use, distribution or reproduction is permitted which does not comply with these terms. 